\title{
MATRIX MATALLOPROTEINASE-8 GENE POLYMORPHISM IN CHRONIC PERIAPICAL LESIONS
}

\author{
Biljana Evrosimovska ${ }^{1}$, Cena Dimova ${ }^{2}$, Lidija Popovska ${ }^{3}$, Efka Zabokova-Bilbilova $^{4}$ \\ ${ }^{1}$ Department of Oral Surgery and Implantology, Faculty of Dentistry, "Ss. Cyril and Methodius" \\ University, Skopje, R. Macedonia \\ ${ }^{2}$ Study for General Stomatology, Faculty of Medical Sciences, University "Goce Delcev" - Stip, \\ R. Macedonia \\ ${ }^{3}$ Department of Restorative Dentistry and Endodontic, Faculty of Dentistry, \\ "Ss. Cyril and Methodius" University, Skopje, R. Macedonia \\ ${ }^{4}$ Department of Pediatric and Preventive Dentistry, Faculty of Dentistry, \\ "Ss. Cyril and Methodius" University, Skopje, R. Macedonia
}

Corresponding Author: Evrosimovska Biljana, Stomatological clinical centre "St Pantelemon", Department of Oral Surgery, Vodnjanska 17; 1000 Skopje, R. Macedonia; E-mail: bevrosimovska@ gmail.com; phone: +389 (0)2 75289925

\begin{abstract}
Background/Aim: Increased levels of matrix metalloproteinase-8 (MMP-8) have been associated with risk of developing chronic periapical lesion (CPL). Gene polymorphisms are contributing factors in the pathogenesis of the inflammation. The aim of this study was to analyze polymorphism in the gene MMP-8 and its association and influence on clinical manifestation of CPL.

Methods: A total of 240 unrelated Macedonian subjects were included in the present study. Polymorphism $-799 \mathrm{C} / \mathrm{T}$ in the gene MMP-8 detected with restriction enzyme $B g I \mathrm{II}$ was studied in 120 patients with CPL and 120 controls without any signs of chronic or acute inflammatory process in the jaw. The amplification of the region of selected gene was made with polymerase chain reactionrestriction fragment length polymorphism (PCR-RFLP).

Results: Our results showed that there were differences in the allele and genotype frequencies of the MMP8 -799 C/T polymorphisms between patients with CPL and controls ( $<<0.05$ ). Also this study suggests that MMP-8 polymorphism -799 $\mathrm{C} / \mathrm{T}$ was a risk for expression of $\mathrm{CPL}$ $(\mathrm{OR}=8.27<3.44<\mathrm{OR}<20.26)$

Conclusion: The detection of this genetic polymorphism is relevant for obtaining providential treatment of patients who are at high risk of chronic periapical inflammation.
\end{abstract}

Key words: chronic periapical lesion, single nucleotide polymorphism, matrix metalloproteinase-8

\section{Introduction}

The possible candidates as biomarkers for periapical inflammation include proteases that are responsible for extracellular matrix ECM degradation such as the matrix metalloproteinases (MMPs) which have fundamental role during the development, remodeling and destruction of oral tissues $[3,5,10]$. The MMPs are a family of zinc-dependent endopeptidases collectively capable of degrading all extracellular matrix com- ponents, including collagen and proteoglycans. The MMPs have been suggested to play an important role in inflammatory conditions of periodontal, pulpal and periapical tissues, as well as dentin mineralization [1]. Tjäderhane et al. demonstrated that in periapical inflamemation MMP inhibition increases the lesion growth rate, indicating that MMPs may have previously unknown anti-infective and/or anti-inflammatory properties [17]. 
The matrix metalloproteinase-8 (MMP-8, collagenase-2) degrades gelatin, type I, II, III, $\mathrm{V}$ and XI collagens [19]. Wahlgren et al. reported that PMN cells and macrophage like cells expressed the staining with MMP-8 specific antibody, the PMN cells being the predominant cell type to express MMP-8 in apical periodontitis [20]. The role of collagenases, especially MMP8 , in apical periodontitis and peri-implantitis is the best-known example of the unwanted tissue destruction related to the increased presence and activity of MMPs at the site of disease, but evidence has been brought forward to indicate that MMPs may also be involved in other oral diseases, such as dental caries and oral cancer [16].

The inflammation involved various genes. Gene polymorphisms are contributing factors in the pathogenesis of inflammation. According to the important role of MMPs in inflammation [11], it has been shown that genetic variation affecting the expression of MMPs influences the susceptibility and progression of various diseases, including chronic periapical lesions (CPLs) [12]. Expression of MMPs is low in normal cells, and these low levels allow for healthy connective tissue remodeling. In pathologic conditions, however, the level of MMP expression increases considerably, resulting in aberrant connective tissue destruction. Expression of MMPs is regulated primarily at the transcriptional level where the promoter of the genes responds to different regulators [9]. Some functional polymorphisms have been described in the regulatory region of MMP genes [21]. Because destructive enzymes of the MMP family are involved in this process, allele polymerphisms of MMP genes are interesting candidates for analyses of the influence, susceptibility and severity of chronic periapical lesions (CPLs) and acute odontogenic infection (AOI).

The aim of this study was to analyze polymorphism -799 C/T in the gene MMP-8 detected with restriction enzyme $B g I I I$ and their association and influence on clinical manifestation of CPL.

\section{Statistical analysis}

Differences between two parameters in series with numeric characteristic were tested with Pearson Chi-Square test. Statistical significance shows that results with values $\mathrm{p}<0.05$. Tests for Hardy-Weinberg equilibrium among groups were conducted with the aim to examine the presence of selective force which effects the distribution of the alleles using observed genotype frequencies and a $\chi 2$ test with one degree of freedom. A risk for developing chronic periapical lesion according to the gene polymorphism of MMP-8 (associative or protective roll) was determined with odd ratio (OR).

\section{Materials and methods}

Patients' samples. A total of 240 patients, both male and female were included in this study, with registration number 2505-135/1, carried out at the Faculty for Dentistry (Clinic for Oral Surgery) in Skopje. The laboratory analyses were done at the Faculty of Natural Sciences and Mathematics (Institute of Biology) in Skopje. This study was done with approval from the Ethical Committee of the University "Goce Delcev" - Stip, Faculty of Medical Sciences, based on the consent signed personally by all the subjects, certifying that each subject has been informed in details regarding the type of analysis and the purpose of taking their examined material (blood), precisely they have given their consent for execution of genetic analysis.

For each patient an application form was prepared, with information for the anamnesis and the clinical investigations (extra oral and intraoral investigations).

From the local dental status in patients with chronic periapical lesions, using clinical methods like dental anamnesis and exhaustive clinical examination, the presence of subjective symptoms: pain, percussion and palpation sensitivity, and of objective symptoms: swelling, drainage of exudates from the root canal, and presence of fistula were obtained and confirmed. These data were expressed by CPI (clinical periapical index).

From the X-ray analyses the following parameters in patients with chronic periapical lesions were registered: condition of the parodontium, presence of chronic periapical lesions, determination of its limits, and presence of bone resorption.

The first group included 120 patients with clinically and radiologically confirmed chronic periapical lesion (CPL). The second (control) group was composed of 120 examinees with solid oral health, without endodontically treated teeth and absence of CPL or AOI. Patients who received antibiotic and immunosupresive therapy were excluded from this study, as well as patients with clinical signs of parodonthal disease. 
In the aseptic conditions, sample of vein blood $(10 \mathrm{~mL})$ was taken from each patient with venipuncture, in a sterile test tube (Vaccutainer ${ }^{\circledR}$ ) containing anticoagulant (EDTA $\left.\mathrm{Na}^{2}\right)$. Each sample was frozen at $-80^{\circ} \mathrm{C}$ as soon as possible and stored until the analysis.

DNA preparation. Standard isolation of genomic DNA from the nuclear cells was performed with natrium chlorid extraction and after words precipitation with ethanol (Gemmel $N J$ and Aniyama $S$. An efficient method for the extraction of DNA from vertebrate tissues. Trends in
Ecology and Evolution 1996; 12(9): 338-339). Samples of DNA isolates were isolated in few test tubes, one of which was kept from $+4^{\circ} \mathrm{C}$ to $+8^{\circ} \mathrm{C}$, and was used for analysis.

The amplification of the regions of elected genes was made with polymerase chain reaction (PCR) and performed in a PCR machine (Perkin-Elmer Gene Amp System 2400). The presence or absence of some normal or mutated sequences in the PCR product was followed through a restriction of the digestion results with different size of fragments (Table 1).

Table 1

Sequence of PCR primers with their restriction enzyme

\begin{tabular}{|c|c|c|c|c|c|c|}
\hline $\begin{array}{c}\text { Gen } \\
\text { name }\end{array}$ & $\begin{array}{c}\text { Polymor- } \\
\text { phism }\end{array}$ & Recognition sequence & PCR conditions & $\begin{array}{c}\text { PCR } \\
\text { fragment } \\
\text { amplifi- } \\
\text { cation }\end{array}$ & $\begin{array}{c}\text { Restric- } \\
\text { tion } \\
\text { enzyme }\end{array}$ & $\begin{array}{c}\text { PCR product } \\
\text { size (bp) }\end{array}$ \\
\hline & & $\begin{array}{c}\text { (F) 5'-GCC AGA GAC TCA AGT } \\
\text { GGG AGA CTA CCA TGC AGA } \\
\text { MMP-8 }\end{array}$ & $\begin{array}{c}35 \text { cycles: } 94^{\circ} \mathrm{C} \\
45 \mathrm{~s}, 56^{\circ} \mathrm{C} 45 \mathrm{~s}, \\
72^{\circ} \mathrm{C} 1 \mathrm{~min}\end{array}$ & $255 \mathrm{bp}$ & BglII & (224+31) bp \\
& $-799 \mathrm{C} / \mathrm{T}$ & $\begin{array}{c}\text { (R) } 5 \text { '- TTA TGA TTG CCC AGA } \\
\text { CAT TTG-3' }\end{array}$ & & & \\
\hline
\end{tabular}

Successful amplification was verified by the presence of electrophoresis marker (PCR Marker, Bio-Rad) with agarelectrophoresis. The production of digestion was visualized with fluorescence painting of the gel with etidium bromid.

Gels were photographed under UV-light with digital camera. Digital pictures were created in Adobe Photoshop, and identification of electrophoretic tracks and calculating of their length was done with the GelPro software.

\section{Results}

The representation of the polymorphism $799 \mathrm{C} / \mathrm{C}$ of the gene for MMP-8 detected with restricted enzyme $B g l I I$ in the patients from examined groups is shown in Table 2. The homozygotes for presence of this polymerphism are marked as $(+/+)$, heterozygotes for presence of this polymorphism are marked as $(-/+)$, and homozygotes for absence of this polymorphism are marked as (-/-).

The representation of the polymorphism of the gene for MMP-8 in the patients from examined groups is shown in Table 2 .

Representation of the polymorphism -799 C/T for the gene of MMP-8 in patients from the examined groups

\begin{tabular}{|c|c|c|c|c|}
\hline \multirow{2}{*}{$\begin{array}{c}\text { Polymorphism } \\
\text { of MMP-8 } \\
\text { detected with } \\
\text { restricted } \\
\text { enzyme } B g l \text { II }\end{array}$} & \multirow[b]{2}{*}{ Number } & \multicolumn{2}{|c|}{ Examined groups } & \multirow[b]{2}{*}{ Total } \\
\hline & & $\begin{array}{c}\text { Chronic } \\
\text { periapical } \\
\text { lesions }\end{array}$ & $\begin{array}{l}\text { Control } \\
\text { group }\end{array}$ & \\
\hline \multirow[b]{2}{*}{-/- } & $\mathrm{N}$ & 44 & 91 & 135 \\
\hline & $\%$ & $36.7 \%$ & $75.8 \%$ & $56.3 \%$ \\
\hline \multirow[b]{2}{*}{$+/+$} & $\mathrm{N}$ & 54 & 25 & 79 \\
\hline & $\%$ & $45 \%$ & $20.8 \%$ & $32.9 \%$ \\
\hline \multirow[b]{2}{*}{$-/+$} & $\mathrm{N}$ & 22 & 4 & 26 \\
\hline & $\%$ & $18.3 \%$ & $3.4 \%$ & $10.8 \%$ \\
\hline
\end{tabular}


The representation for presence of polymorphism for the gene of MMP-8 with restricttion enzyme $B g I I I$ in the patients with chronic periapical lesions was $45 \%$ in homozygotes, and $18.3 \%$ in heterozygotes. The representation for absence of polymorphism for the gene of MMP-8 in patients with chronic periapical lesions was $36.7 \%$. The representation for presence of polymorphism for the gene of MMP-8 with restriction enzyme $B g I I$ in the patients from the control group was $20.8 \%$ in homozygotes and $3.4 \%$ in heterozygotes. The representation for absence of polymorphism for the gene of MMP-8 in patients from control group was $75.8 \%$.
Table 3 shows data about the signs of positive symptomatology in patients with chronic periapical lesions which are in correlation with the existence of clinical symptoms in the period of making the appointment or operating the oralsurgery interventions and their manifestations are marked with CPI (clinical periapical index).

The analysis of the data for the correlation of the CPI index with polymorphism of the gene for MMP-8 shows that there was a statistical significance between the CPI index and the investigated polymorphism in patients with chronic periapical lesions (Pearson Chi-square: 13.5999, $\mathrm{df}=2, \mathrm{p}=0.001114$ ) (Table 3).

Table 3

Representation of the CP index in patients

\begin{tabular}{|c|c|c|c|c|c|}
\hline & & & $\begin{array}{c}\text { Chronic periapic } \\
\text { lesions }\end{array}$ & Control group & Total \\
\hline \multirow{6}{*}{ 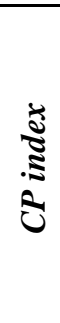 } & \multirow[b]{2}{*}{1} & Number & 53 & 120 & 173 \\
\hline & & $\%$ & 444.2 & 100 & 72.1 \\
\hline & \multirow[b]{2}{*}{2} & Number & 67 & 1 & 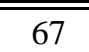 \\
\hline & & $\overline{\%}$ & 27.9 & 1 & $\overline{27.9}$ \\
\hline & \multirow[b]{2}{*}{3} & Number & 1 & 1 & 1 \\
\hline & & $\overline{\%}$ & 1 & 1 & 1 \\
\hline
\end{tabular}

The results from the analysis of the data for the correlation between the number of carious teeth and polymorphism $-799 \mathrm{C} / \mathrm{T}$ for the gene of MMP-8 show that there is a statistical significance between polymorphism and patients with higher number of carious teeth. This result shows that there was a mutation of the gene for MMP-8 in patients with higher number of carious teeth (Pearson Chi-square: 60.8077, $\mathrm{df}=4$, $\mathrm{p}=0.000000)($ Table 4).

Table 4

Representation of carious teeth in patients

\begin{tabular}{|c|c|c|c|c|c|c|}
\hline \multirow{2}{*}{$\begin{array}{c}\text { Examined } \\
\text { patients }\end{array}$} & \multicolumn{4}{|c|}{ Number of carious teeth } \\
\cline { 2 - 7 } & \multicolumn{2}{|c|}{ No carious teeth } & \multicolumn{1}{|c|}{$\mathbf{1 - 5}$ carious teeth } & \multicolumn{2}{c|}{$>$ 5 carious teeth } \\
\cline { 2 - 7 } & Number & $\%$ & Number & $\%$ & Number & $\%$ \\
\hline Chronic periapical lesions & 21 & $17.5 \%$ & 66 & $55 \%$ & 33 & $27.5 \%$ \\
\hline Control group & 97 & $80.8 \%$ & 21 & $17.5 \%$ & 2 & $1.7 \%$ \\
\hline Total & 118 & $98.3 \%$ & 87 & $72.5 \%$ & 35 & $29.2 \%$ \\
\hline
\end{tabular}

\section{Hardy- Weinberg equilibrium}

The frequency of the allele is expressed through the number of genotype and frequency of the genotypes. The frequency of the allele A (p) and allele a (q) is always one $(p+q=1)$. If there is a Hardy-Weinberg equilibrium, the fre- quency of the allele will not be changed from generation to generation. On the base of the frequency of the alleles $(p, q)$ we can calculate the frequency of the genotypes $\left(p^{2}+2 p q+q^{2}\right)$ with the Hardy-Weinberg equilibrium. The allele and genotype frequencies of the MMP-8 
polymorphism in patients with chonic periapical lesions and controls are shown in tables 5 and 6.

In patients with chronic periapical lesions, the frequency of the allele $\mathrm{C}, \mathrm{f}(\mathrm{C})$ is 0.46 , of the allele $\mathrm{T}, \mathrm{f}(\mathrm{T})$ is 0.54 respectively $0.46+0.54=1$. The frequency of the genotypes is: $\mathrm{f}(\mathrm{C} / \mathrm{C})=$ $0.5 ; \mathrm{f}(\mathrm{C} / \mathrm{T})=0.1 ; \mathrm{f}(\mathrm{T} / \mathrm{T})=0.4$. Due to the value of $p<0.05(p=0.0000)$, there is an equilibrium in the population for this locus (Table 5).

Table 5

The allele and genotype frequencies of the MMP-8 polymorphism in patients with clinical diagnosis of chronic periapical lesion

\begin{tabular}{|c|c|c|c|c|c|}
\hline Genotype & $\mathrm{C} / \mathrm{C}$ & $\mathrm{C} / \mathrm{T}$ & $\mathbf{T} / \mathbf{T}$ & Total & $\begin{array}{l}\text { Frequency of } \\
\text { the allele }\end{array}$ \\
\hline Number $(n)$ & 44 & 22 & 54 & 120 & 240 \\
\hline allele C & 88 & 22 & 0 & 110 & 0.46 \\
\hline allele $\mathrm{T}$ & 0 & 22 & 108 & 130 & 0.54 \\
\hline $\begin{array}{l}\text { Observed } \\
\text { frequency }\end{array}$ & $\begin{array}{c}44 \\
(36.67 \%)\end{array}$ & $\begin{array}{c}22 \\
(18.33 \%)\end{array}$ & $\begin{array}{c}54 \\
(45 \%)\end{array}$ & $\begin{array}{c}120 \\
(100 \%)\end{array}$ & 240 \\
\hline $\begin{array}{c}\text { HW - Expected } \\
\text { frequency }\end{array}$ & $\begin{array}{c}25.21 \\
(21.01 \%) \\
\end{array}$ & $\begin{array}{c}59.58 \\
(49.65 \%)\end{array}$ & $\begin{array}{c}35.21 \\
(29.34 \%)\end{array}$ & $\begin{array}{c}120 \\
(100 \%)\end{array}$ & \\
\hline cell Chi-sq. & 14.008 & 23.706 & 10.030 & 47.744 & \\
\hline $\mathrm{p}$ - value & & & & 0.00000 & $\begin{array}{c}\text { (p-value) } \\
\text { Chisq w } 1 \text { df }\end{array}$ \\
\hline
\end{tabular}

In patients from the control group, the frequency of the allele $\mathrm{C}, \mathrm{f}(\mathrm{C})$ is 0.78 , of the allele $\mathrm{T}, \mathrm{f}(\mathrm{T})$ is 0.23 respectively $0.78+0.23=1$. The frequency of the genotypes is: $\mathrm{f}(\mathrm{C} / \mathrm{C})=0.7$;
$\mathrm{f}(\mathrm{C} / \mathrm{T})=0.1 ; \mathrm{f}(\mathrm{T} / \mathrm{T})=0.2$. Due to the value of $\mathrm{p}<0.05(\mathrm{p}=0.0000)$, there is an equilibrium in the population for this locus (Table 6).

Table 6

The allele and genotype frequencies of the MMP-8 polymorphism in patients from the control group

\begin{tabular}{|c|c|c|c|c|c|}
\hline Genotype & $\mathrm{C} / \mathrm{C}$ & $\mathrm{C} / \mathrm{T}$ & $\mathbf{T} / \mathbf{T}$ & Total & $\begin{array}{l}\text { Frequency of the } \\
\text { allele }\end{array}$ \\
\hline Number $(n)$ & 91 & 4 & 25 & 120 & 240 \\
\hline allele C & 182 & 4 & 0 & 184 & 0.78 \\
\hline allele $\mathrm{T}$ & 0 & 4 & 50 & 54 & 0.23 \\
\hline $\begin{array}{l}\text { Observed } \\
\text { frequency }\end{array}$ & $\begin{array}{c}91 \\
(75.83 \%)\end{array}$ & $\begin{array}{c}4 \\
(3.33 \%)\end{array}$ & $\begin{array}{c}25 \\
(20.83 \%)\end{array}$ & $\begin{array}{c}120 \\
(100.00 \%)\end{array}$ & 240 \\
\hline $\begin{array}{c}\mathrm{HW} \text { - Expected } \\
\text { frequency }\end{array}$ & $\begin{array}{c}72.08 \\
(60.06 \%)\end{array}$ & $\begin{array}{c}41.85 \\
(34.88 \%)\end{array}$ & $\begin{array}{c}6.08 \\
(5.06 \%)\end{array}$ & $\begin{array}{c}120.00 \\
(100.00 \%)\end{array}$ & \\
\hline cell Chi-sq. & 4.969 & 34.232 & 58.956 & 98.157 & \\
\hline $\bar{p}$ - value & & & & 0.0000 & $\begin{array}{c}\text { (p-value) } \\
\text { Chisq w } 1 \text { df }\end{array}$ \\
\hline
\end{tabular}

The statistical analysis confirms that there is a statistical significance between gene polymorphism of MMP-8 and the chronic periapical lesions (Pearson Chi-square: 37.6919, $\mathrm{df}=2, \mathrm{p}=0.000000)$. The polymorphism -799
$\mathrm{C} / \mathrm{T}$ for the gene of MMP-8 detected with the restricttive enzyme $B g l \mathrm{II}$ was a risk factor for expression of the chronic periapical lesion $(\mathrm{OR}=8.27<3.44<\mathrm{OR}<20.26)$. 


\section{Discussion}

Considering the contribution of unregulated MMPs expression in a wide range of diseases including arthritis, atherosclerosis, and periodontitis and cancer, the expression of these proteases may serve as therapeutic targets in these pathological conditions. The expression and activity of MMPs in adult tissues is normally quite low, but increases significantly in various pathological conditions that may lead to unwanted tissue destruction, such as inflammatory diseases, tumor growth and metastasis. MMPs also have a marked role in tissue destructive oral diseases. The role of collagenases, especially MMP- 8 , in periodontitis and peri-implantitis is the best-known example of unwanted tissue destruction related to the increased presence and activity of MMPs at the site of disease, but evidence has been brought forward to indicate that MMPs may also be involved in other oral diseases, such as dental caries and oral cancer [16].

Genetic polymorphisms have historically been used as genetic markers to locate diseasecausing genes through linkage studies. However, there is an increasing appreciation that they may directly influence complex common diseases via a direct effect on the gene function. By definition a genetic polymorphism is a nucleotide sequence at a particular position (locus) in the DNA molecules exhibiting at least two variants (alleles) that occur in $>1 \%$ of the population [14]. Thus, if the locus is biallelic, the most common variant among them occurs in $<99 \%$ of the population at large. There are a number of different types of nucleotide structures in the human genome that fit the definition of genetic polymorphism.

Polymorphisms in MMP genes may result in changes in the expression of MMPs being associated with the development and progression of cancer. The study of González-Arriaga $P$ et all, suggests that the MMP1 and MMP13 promoter polymorphisms were not associated with lung cancer risk, while the $\mathrm{C} / \mathrm{G}$ polymerphism in MMP8 was associated with a statistically significant decreased risk of developing lung cancer $(\mathrm{OR}=0.65 ; 95 \% \mathrm{CI}=0.45-0.93)$ [3].

Several studies show that MMPs are associated with CPLs, but studies with MMP polymorphisms are relatively few and have produ- ced controversial results. In the study of Menezes-Silva $\mathrm{R}$ et all, it is shown that polymerphisms in MMP genes and their regulators contribute to an individual's increased susceptibility to apical tissue destruction in response to deep carious lesions [8]. The variation of the alleles in genes of collagenases, as well as the factors which regulate their expression, result in differences in the phenotypes of collagenases between individuals, which is of enormous significance when it comes to the sensibility to diseases and their frequencies. The results from several reviews $[6,7,15]$ on gene polymerphisms associated with periodontitis revealed that data from studies on the same gene polymorphism have not always been consistent, which may reflect the complexity and heterogeneity of the genetic influence in periodontitis. The results of the previous studies suggest that this polymorphism may have a functional consequence as it affects the functions of the MMP-8 enzyme [12] and represents a candidate polymorphism of a strong biological relevance to the development of the chronic inflammatory diseases [18]. A single nucleotide polymerphism of the gene for MMP-8 has influence on the transcriptional activity of those collagenases, increasing the level of protein expression [4].

\section{Conclusion}

The examined polymorphism $-799 \mathrm{C} / \mathrm{T}$ of the gene for MMP-8 with the restriction enzyme $B g I I I$ correlated with the CPLs and AOIs in the Macedonian population. The detection of this genetic polymorphism is of great relevance for obtaining providential treatment of the patients who are with high risk of inflammation.

\section{REFERENCES}

1. Buzoglu HD, Unal H, Ulger C, Mert S, Kücükyildirim S, Er N. The zymographic evaluation of gelatinase (MMP-2 and -9) levels in acute and chronic periapical abscesses. Oral Surg Oral Med Oral Pathol Oral Radiol Endod. 2009; 8(5): 121-6.

2. De Paula e Silva F, D'Silva N, Bezerra da Silva L, Kapila Y. High Matrix Metalloproteinase Activity is a Hallmark of Periapical Granulomas. J Endod. 2009; 35(9): 1234-1242.

3. González-Arriaga P, Pascual T, Marrón M G, Puente $\mathrm{X} \mathrm{S}$ and Tardón A. Polymorphism $+17 \mathrm{C} / \mathrm{G}$ in Matrix Metalloprotease MMP8 decreases lung cancer risk. BMC Cancer. 2008; 8: 378. 
4. Hannas AR, Pereira JC, Granjeiro JM, Tjäderhane L. The role of matrix metalloproteinases in the oral environment. Acta Odontol Scand. 2007; 65(1): 1-13.

5. Kinane DF, Shiba H, Hart TC. The genetic basis of periodontitis. Perio 2000 2005; 39: 91-117.

6. Loos, BG, John RP, Laine ML Identification of genetic risk factors for periodontitis and possible mechanisms of action. J. Clin. Periodontol. 2005; 32 (6): 159-179.

7. Menezes-Silva R, Khaliq S, Deeley K, Letra A, Vieira AR. Genetic Susceptibility to Periapical Disease: Conditional Contribution of MMP2 and MMP3 Genes to the Development of Periapical Lesions and Healing Response. Journal of Endodontics. 2012; 38(5): 604-607.

8. Nagase H and Woessner Jr JF. Matrix metalloproteinases. J Biol Chem. 1999; 274: 21491-21494.

9. Page-McCaw A, Ewald AJ, Werb Z. Matrix metalloproteinases and the regulation of tissue remodeling. Nat Rev Mol Cell Biol 2007; 8(3): 221-233.

10. Parks WC, Wilson CL, López-Boado YS. Matrix metalloproteinases as modulators of inflammation and innate immunity. Nat Rev Immunol. 2004; 4: 617-629.

11. Rutter JL, Mitchell TI, Buttice G et al. A single nucleotide polymorphism in the matrix mealloproteinas1 promoter creates an Ets binding site and augments transcription. Cancer Res. 1998; 58: 5321-5.

12. Scherer S, Barboza de Souza T, Juliana de Paoli, Brenol CV, Xavier RM, Brenol JCT, Chies JA, Simon D. Matrix metalloproteinase gene polymorphisms in patients with rheumatoid arthritis. Rheumatol Int. 2010; 30: 369-373.

13. Schork NJ, Fallin D, Lanchbury JS. Single nucleotide polymorphisms and the future of genetic epidemiology. Clin Genetics. 2000; 58: 250-264.

14. Shapira L, Wilensky A, Kinane DF. Effect of genetic variability on the inflammatory response to periodontal infection. J Clin Periodontol. 2005; 32(6): 72-86.

15. Sorsa T, Tjäderhane L and Salo T. Matrix metalloproteinases (MMPs) in oral diseases. Oral Diseases. 2004; 10(6): 311-318.

16. Tjäderhane L, Hotakainen T, Kinnunen S, Ahonen M, Salo T. The effect of chemical inhibition of matrix metalloproteinases on the size of experimentally induced apical periodontitis. Int Endod J. 2007; 40(4): 282-9.

17. Vincenti MP, White LA, Schroen DJ, Benbow U, Brinckerhoff CE. Regulation expression of the gene for matrix metalloproteinase-1 (collagenase): mechanisms that control enzyme activity, transcription, and mRNA stability. Crit Rev Eukaryot Gene Expr. 1996; 6: 391-411.

18. Wahlgren J, Maisi P, Sorsa T, Sutinen M, Tervahartiala T, Pirilä E, Teronen O, Hietanen J, Tjäderhane L \& Salo T. Expression and induction of collagenases (MMP-8 and -13) in plasma cells associated with bone-destructive lesions. J Pathol. 2001; 194: 217-224.

19. Wahlgren J, Salo T, Teronen O, Luoto H, Sorsa T \& Tjäderhane L. Matrix metalloproteinase-8 (MMP-8) in pulpal and periapical inflammation and periapical root-canal exudates. Int Endod J. 2002; 35: 897-904.
20. Ye S. Polymorphism in matrix metalloproteinase gene promoters: Implication in regulation of gene expression and susceptibility of various diseases. Matrix Biol. 2000; 19: 623-629.

Резиме

\section{ГЕНЕТСКИ ПОЛИМОРФИЗАМ НА МАТРИКС МЕТАЛОПРОТЕИНАЗА-8 КАЈ ХРОНИЧНИТЕ ПЕРИАПИКАЛНИ ЛЕЗИИ}

\section{Билјана Евросимовска ${ }^{1}$, Цена Димова ${ }^{2}$, Лидија Поповска ${ }^{3}$, Ефка Забокова-Билбилова ${ }^{4}$}

${ }^{1}$ Клиника за орална хирургија и

имплантологија, Стоматолошки факултет, Универзитет „Св. Кирил и Методиј“, Скопје, Р. Македонија

${ }^{2}$ Студии по општа стоматологија, Факултет за медицински науки, Универзитет „Гоце Делцев“" - Штип, Македонија

${ }^{3}$ Клиника за реставративна стоматологија и ендодонција, Стоматолошки факултет, Универзитет „Св. Кирил и Методиј“, Скопје, Р. Македонија

${ }^{4}$ Клиника за детска и превентивна стоматологија, Стоматолошки факултет, Универзитет „Св. Кирил и Методиј“, Скопје, Р. Македонија

Цел: Зголемените нивоа на матрикс металопротеиназата-8 (ММП-8) се во асоцијација со ризик од развој на хронична периапикална лезија (ХПЛ). Генетските полиморфизми претставуваат фактори што придонесуваат во патогенезата на воспалитениот процес. Целта на оваа студија е да се анализира полиморфизмот на генот на ММП-8 и неговата асоцијација и влијание врз клиничката манифестација на ХПЛ.

Metogu: Вкупно 240 пациенти од македонска националност беа вклучени во оваа студија. Полиорфизмот -799 Ц/Т во генот на ММП-8 беше детектиран со рестрикциски ензим БgИИИ кај 120 пациенти со ХПЛ и кај 120 пациенти од контролната група кај која не постоеја знаци на хроничен или акутен инфламаторен процес во вилицата. Амплификацијата на регионот од селектираниот ген е извршена со полимеразна верижна реакција (ПЦР-РФЛП).

Резул $а$ tu: Резултатите потврдуваат дека постојат разлики во фреквенцијата на алелите и генотиповите кај полиморфизмот -799 ЦТ на генот од ММП-8 помеѓу пациентите со ХПЛ и 
оние од контролната група (п < 0.05). Со оваа студија се потврдува дека испитаниот полиморфизам претставува ризик-фактор од експресија на ХПЛ $(\mathrm{OP}=8.27<3.44<\mathrm{OP}<20.26)$.

Заклучок: Детекцијата на овој генетски полиморфизам е од особена важност за да се обез- беди адекватен третман на пациентите кои се со висок ризик од развој на ХПЛ.

Клучни зборови: хронична периапикална лезија, единечен нуклеотиден полиморфизам, матрикс металопротеиназа- 8 